\title{
CURRENT TRENDS IN THE SOCIAL-ECONOMIC INTEGRATION OF GYPSY MIGRANTS IN THE EUROPEAN UNION
}

\author{
E. Marushiakova, V. Popov \\ School of History at University of St. Andrews \\ South str., 71, St Andrews Scotland, UK \\ Institute of Ethnology and Folklore Studies with Ethnographic Museum \\ at Bulgarian Academy of Sciences \\ Moskovska str., 6a, Sofia, Bulgaria, 1000
}

\begin{abstract}
Gypsies are not an isolated group, they have a multifaceted identity and national individuality. In order to identify the nature and determinants of Roma migrations, they should be given attention as an ethnically specific community. Roma migration in the past and in the present are dictated by the collective strategies in response to current political and economic changes. Deceptive inconsistency of Gypsy migrations is explained by the heterogeneity of the Roma communities themselves and is manifested in various ways in different countries. Currently, the main participants of the migration are not a community of nomads, but the representatives of the settled Roma communities. The reason for this situation is the significant increase of integration of Roma in the countries of Eastern Europe. This leads to the inclusion of Roma in global migration processes.
\end{abstract}

Key words: migration crisis, migration of Roma, integration of Roma, ethnic identity, the European Union

\section{Introduction}

In recent years, the Refugee Crisis has emerged as a major challenge before the united Europe, which threats its unity and even questioned the future existence of the very Union. However, this crises does not remove but rather compliment other serious issues faced by the European Union, including the issue of integration of migrants and on the first instance the "Roma inclusion" into the societies of European Union countries (including countries such as Western Balkans and Turkey, which are in one or another way associated to EU).

Gypsies in Eastern Europe

Immediately after breaking down of the so-called socialist camp the fate of the Gypsies in former communist countries attracted attention of wide circle of personalities and institutions from the West, such as policy makers, human rights advocated, NGO and foundations and individual scholars as well and very quickly various in scale, direction and content initiatives for improving their situation were inducted. The Gypsies started be called Roma, which is considered now the only one politically correct term. After the accession of most of countries of the former Soviet bloc to the European Union, the socalled "Roma issue" has become, from a problem specific for the Eastern European countries in transition, one of the leading themes in pan-European public space. At the 
backdrop of this public interest there are the mass migrations of Gypsies from East to West and the efforts were directed towards improvement of their human rights situation, introduction of antidiscrimination laws. This was thought will pave road to integration, which will make Roma stay in their countries of origin. The failure of national integration policies towards the Gypsies in Eastern Europe became a failure of national integration policies towards the Gypsies in Western Europe as well. After more than two decades it is already clear that there is a complete failure in policies for Gypsies inclusion on a panEuropean level. At the end, the contemporary policies of inclusion don't lead either to a decrease in rate of Gypsy migration, nor to Gypsies integration in their home countries or host countries, and if there is successful Gypsies migrants' inclusion it is in spite, not because of the policies.

In our previous publications we offered explanation of this at first glance shocking conclusion reviewing the main patterns of the Gypsy migrations from Eastern to Western Europe. (Marushiakova, Popov, 2015). In order to better understand the historical and modern patterns of Gypsy migrations also the specifics of Gypsies as an ethnic community and their historical fate should be taken into account too. The Gypsies, whose historical areal are the countries of Central, Eastern and Southeastern Europe, are non-homogeneous socio-cultural unit and that is hierarchically structured on different taxonomical levels. They are descendants of early (at least a thousand years ago) migrants from Indian subcontinent and have existed for centuries in a social structure, which we defined as an 'Inter-group Ethnic Formation'; this community is divided into a number of separate groups, subgroup divisions, and meta-group units, each with its own social and cultural features (Marushiakova, Popov, 2008, 2013). The Gypsies speak different dialects of their language, known as Romanes or Romani language (Matras Y., 2002), profess different religions (mainly different Christian denominations and Islam, and in the recent years there has been a stormy expansion of various new Protestant denominations), and are characterized by quite diverse ethno-cultural parameters. Many of them no longer speak Romanes and have accepted other basic languages (Turkish, Albanian, Romanian, Hungarian, Ukrainian, etc.), and are with preferred ethnic identity (i.e. they prefer to identify as another ethnicity, e.g. as Turks, Greeks, Romanians, Hungarians, etc. (Marushiakova, Popov, 2013, 2015). Some of them also even try to create their own new, entirely different ethnic identity, such as the Balkan Egyptians and A kali in the countries of former Yugoslavia and Albania (Marushiakova, Popov, 2001, 2013).

These communities are constructed on different hierarchical levels, and depending of different kinds of factors and in different context, one or another of these levels could be main, leading and determining. To the each level corresponds respective identity, thus the Gypsies are characterized by multidimensional identities. Different dimensions of these identities can be performed as subgroup, group, metagroup, or at the national or supranational levels. Together with this community ethnic identity all Gypsies units possess also national identity, a feeling of belonging to the civic nation of the state which citizens they are, or in migration, which have been in the recent past (Marushiakova, Popov, 2008, 2013).

The Gypsies are not a hermetically isolated and self-sufficient social and cultural system. They have always existed at least in two dimensions, or in two coordinate plans. This fundamental principle is based on the juxtaposition "community - society" which 
should be understand as relations between two simultaneously existing typological phenomena intertwined in one inseparable unity. In this case, 'community' means the Gypsies as an Inter-group ethnic formation, clearly distinguished from its surrounding population; and 'society' means the Gypsies as part of the respective nation-state, which citizens and ethnically-based integral part the Gypsies are (Marushiakova, Popov, 2008). In order to reveal the nature of the processes of Gypsy migrations the attention should be paid to them as ethnically specific community, that at the same is an integral part and constituent element of their respective civic nations (Marushiakova, Popov, 2013).

In the Gypsies' history, after their arrival in Europe from India and their stay for several centuries on, their migrations have formed a repetitive pattern (Matras Y., 2000) in which we can distinguish some big and several smaller migration waves, where they have crossed state borders, dispersed in new territories, and reclaimed new social and economic spaces (Marushiakova, Popov, 2006). The Gypsy migrations in the past and nowadays are driven by the demand for collective strategies in response to the ongoing political and economic changes, and they appear to be more or less non-coherent in practice, due to heterogeneity of the Gypsy communities and since the situation in various countries is different (Marushiakova, Popov, 2008).

In the history of the Gypsies after their arrival from the Indian subcontinent to Europe, there were three big waves of migration. About first two migration wave, which were predominantly movement of communities of service nomads, we wrote extensively elsewhere (Marushiakova, Popov, 2008, 2012).

The current third migration wave began in the 1960s and continued to the present (Marushiakova, Popov, 2006; Reyniers A., 1999). It could be defined as one common migration wave, in spite of its non-homogeneity and different main characteristics along the years. The nature of this third wave is different in comparison with the first two waves. In contrast to the previous two waves, the main bearer of the migration today are no longer the communities of nomads, but representatives of settled Gypsies communities, and the formers nomads, sedentarised in the times of socialism, are only a less significant part of it. The reasons for this change is primarily the increased degree of social integration of Gypsies in countries of Eastern Europe, leading to the inclusion of Gypsies in the general migration processes flowing within the societies of which they are an integral part.

In the frames of this third wave we can distinguish following four types of migration: 'Gastarbeiter' from Yugoslavia; Political and quasi-political asylum seekers; Refugees from war and ethnic cleansing in the former Yugoslavia; Transborder labor mobility within the European Union. These four basic types of migrations often fully or only partially overlap as chronology. They are not unchangeable, one type could transfer to another, and in the end eventually all four types may lead to permanent settlement of Gypsies from Eastern in Western Europe (Marushiakova, Popov, 2013).

\section{Types of Gypsies migration}

It is this very variability that unites all these types of Gypsies migration into one separate wave. Another, even more important reason, which enable their categorization into one pattern is the fact that all these type of migration bear a common feature of "post- 
modernity". If we are using the categories of the aforementioned distinction of Gypsies as a 'community' and 'society', in the third wave of migration dominates migrating of Gypsies as a 'society', i.e. as an integral (though ethnically detached) part of the general migratory flows from the countries of Eastern Europe to the West (mainly to the Western Europe, and in smaller number to USA and Canada as well). Individual cases of Gypsies, migrating as part of the society, appeared occasionally already in times of the second migration wave, but now this is a predominant pattern. After EU accession of most countries in Eastern Europe and the fall of the visa obligations the processes of transborder labor mobility (already legal) was accepted in masse. The countries preferred by the migrants from individual Southeastern and Central European countries are different, as are the ways of legalization, preferred occupation and so on, but in any case, the Gypsies' migration mirror the mainstream migration wave which encompasses all Europe (Marushiakova, Popov, 2013).

In conditions of the migration, when Gypsies from Eastern Europe remain permanently settled in Western Europe and turn into local citizens, they preserve themselves as a Gypsy community, but at the same time they remain (at least for now) linked to national migrant diasporas of the relevant countries of origin. Moreover, Gypsies in migration maintained a much higher level contacts with their respective national diasporas than with Gypsy migrants from other countries or with Gypsies from their host countries. Specific case are Gypsy communities with preferred Turkish identity from Bulgaria, who in the conditions of emigration are using networks of migrants from Turkey for settling in host countries (mainly in Germany, Netherlands and Belgium) and are striving for melting with Turkish migrant diaspora in these countries (Marushiakova, 2014). We named this type of movement when Gypsies move to other countries, as inseparable part of the society, an "invisible" or "hidden" Roma migration. In fact, in this case more appropriate would be to speak about not about migration but about labor mobility, at least in case of Gypsies from Eastern European countries which are already members of European Union and de-jure are using the rule of free movement in Europe. Paradoxically, in spite of the fact that this "invisible" Roma migration is about the majority of them, no general public, nor policy makers, nor even most academics seen to be aware of it.

Parallel to this there are still cases, however, not so numerous, when Gypsies migrate as separate ethnic community and are highly visible in public sphere. The beginning of these processes was in the end of the 1980s, when in Germany, under the active influence of human rights organizations a public campaign for legalization the statute of the Gypsies, migrants from Yugoslavia started, however perceived them not as Yugoslavian citizens, but as a separate community (Matras Y., 1998; 2000). The theme of violated human rights of the minorities and the discrimination of the Gypsies in Eastern Europe gives new political dimensions to the attempts of Gypsies to migrate from these countries, trying to receive political shelter in different countries in Western Europe (as well as in USA and Canada) as persecuted in their countries communities. These migrations (or attempts for migration) are uneven in scale, chronology, and country of origin and heading, and are in dependence of different circumstances. Such are for instance the attempts of Gypsies from Bulgaria and Romania to receive political asylum in Germany in 19911993; the emigration of Gypsies from Poland and the Baltic states to Great Britain during 
the second half of the 1990s; the emigration of Gypsies from Czech Republic, Slovakia and Hungary to Canada, which stated to receive bigger and bigger dimensions after 1997; the entrance of Gypsies from Czech Republic and Slovakia to Great Britain in 1997 and later, in Belgium and Finland during 1999-2000, etc. (Grill J., 2011; 2012; Klimova I., Pickup A., 2000; Kotvanova A., Szep A., 2002; Kovats A., 2002; Vidra Z., 2013). The end of these type of migration occurs following European Union accession of the Eastern European countries and now the only country continuing to accept (although reluctantly) Gypsies as refugees remains Canada.

The case with Gypsy refugees from former Yugoslavia is more specific, but it is also a form of migration of Gypsies as a separate community. After the collapse of the country, as a result of the following wars and ethnic cleansing, big groups of Gypsies migrated westwards. The first migration currents were in the beginning of the 1990s when during the Bosnia war (1992-1995) many Gypsies headed towards Italia. Especially huge were the migrations from Kosovo after the NATO bombing of Serbia in 1999 and the following ethnic cleansing, carried out by the local Albanians, when many 'Roma, Egyptians and Ashkali' (according to the accepted terminology) were forced to leave the province and to escape to Serbia and Montenegro and Macedonia, where they live under the status of IDP (Internally Displaced Persons). Many of them manage to reach Western Europe (mainly Germany), where they also remain with unclear status and are under the continuous threat to be deported back to Kosovo, in spite the fact that the international forces and local authorities there are unable to assure their safety. In Italy all these Gypsy refugees automatically were declared to be "nomads" and according to these criteria they were exempt from the programs for integration of other refugees and migrants and were directly accommodated in the so-called "campi nomadi" 1 .

The migrations of Gypsies as a "community" received new forms and dimensions after 2001, after the fall of visa restrictions for most of the countries in Eastern Europe. In their vast majority the bearers of the new migration strategy are parts of Gypsies from Romania. They are heading towards Italy, France, Spain and Portugal, and in smaller numbers also to Great Britain, Ireland and Nordic countries. They are using centuriesold tactics for earning their living: begging on the street of big towns. Because of their way of earning their living and specific women's dress, they are visible in the eyes of surrounding population of accepting them countries and so they are transformed into the stereotyped image of the Gypsies migrants as a whole (Marushiakova, Popov, 2013). In this way the migrations of Romanian Gypsies are more "visible" for the local authorities and the media, while other Gypsy migrants, for example the Bulgarian Gypsies in Italy, remain largely away from (and mostly unknown) the public interest of researchers and authorities (Zahova S., 2013). In academia as well in policy on local, national and supranational level these visible Roma are equated to the refugees and forced migrants. Both categories are conceived as 'vulnerable migrants' that need to be protected and main practical efforts of the institutions is to distinguish between 'fake' and 'real' vulnerable ones among them, to understand to whom of them should be applied the asylum and refugee norms, how to secure their place of living in a way which will not make burden

${ }^{1}$ European Roma Right Centre (ERRC). Campland: Racial segregation of Roma in Italy. Budapest: European Roma Right Centre, 2000. 
to specific localities. Another issue is the responsibility for solving their numerous problems and there is observed kind of competition between different stakeholders of care givers from one side and decision maker on different levels starting from local authorities, individual states or and transnational institutions. In the end the visible Roma migrants attract humanitarian assistance and are put under a strong patronizing approach.

In direct relation to this is the question about the causes of Gypsy migrations. In various scholarly works we found different answers from stereotypical, romanticizing explanation, e.g. Roma migrations are "way of maintaining their freedom and cultural vitality" to underlining the issues of poverty and discrimination. As follow up we can see conclusions, like e.g. "[Roma migrants are] caught in this vicious circle, unable to trust either western or eastern European societies, individual applicants are confronted with a choice between coming to terms with a long-term clandestine existence, and adopting an attitude of non-cooperation-in-principle with the majority or gadje society" (Matras Y., 2000). In the majority of cases, however, the reality is different - the causes of Gypsy migration in the West are the same like for surrounding population - the hard social and economic crisis of the time of the transition. High unemployment rate especially among the Gypsies and increase of antigypsyism and discriminatory attitudes are just additional factors pushing Gypsies to migrate and increase the size of mobility. And in this migration as well as in adapting to host country Gypsies cooperate closely with representatives of the majority societies from their countries of origin and from host countries too.

Having in mind that majority of Gypsies today migrate in majority cases as part of the society of their countries of origin we can disclose the main reason for migration to the West today, for both Gypsies and non-Gypsies as well. This appears on the first place to be the huge difference in the living standards in East and West. In certain occupations the ratio between the salaries in East and West can reach 1:10 and even more, and when speaking about the size of social welfare that is possible to receive in the West it exceeds in some cases the amount of any wages in the countries of origin of the migrants. So it is completely understandable that the Gypsies, including those with good qualifications, are an integral part of the national migration flows in the West. Even hypothetically if we imagine that all social and economic problems which are specific for Gypsies in Eastern Europe disappear and they will become truly equal with majority, this will not change their life strategies oriented at migration in the West (or will change them only to a minor degree). In this sense, all EU programs and projects that are implemented in Eastern and Western Europe, aimed at limiting only the Gypsies migrations to the West and not to equalizing the living standards in both part of Europe are doomed to failure.

The outcomes of the current Gypsy migration to the West have different dimensions. On the one hand, the migrating Gypsy families who settle permanently in the Western European countries, who are already part of the huge "invisible" migration from the East, are mitigating the continuing dependency of western European market structures on low-skilled or skilled immigration workers thus in the end is profitable for the West. On the other hand, in results of migration, in Eastern Europe remain to live mostly marginalized parts of the local Gypsy communities, unable to migrate with low social literacy and without any qualification. This further complicates and undermines the efforts for their successful social integration. In this situation, development prospects of 
the Gypsy migration from East to West is difficult to predict, especially in the more distant future, but it is clear already now that they affect particularly negatively the Gypsies who stay in their homelands.

\section{Conclusion}

This situation poses new challenges for the United Europe. It turns out that the united Europe cannot provide social integration of a significant parts of its citizens (in European official documents the number of 10-12 million Roma living in Europe is quoted). And problems with their integration are encountered in the East (it is explained as a legacy of socialism), but increasingly also in the West. Attempts to limit the Gypsy migrations in the West and the transfer of responsibility for social integration of Roma on countries in Eastern Europe. In case of Eastern European countries which are already members of European Union this actually constitutes a breach of a fundamental principle upon which is built a united Europe - the free movement of people, goods and capitals. The adoption of the European Framework of National Roma Inclusion Strategies 2011, which obliges EU member states to develop their national strategies for solving the problems of Roma did not lead to any real consequences. And something more - it cannot lead to any positive change in situation when the most active part of their communities is pushed to migration. Therefore, the prospects for social integration of Roma in European Union are not encouraging at all, they are just on the contrary (Marushiakova, Popov, 2015). The prospects for integration of Roma who originate from countries apart of European Union are even more desperate.

\section{REFERENCES}

European Roma Right Centre (ERRC). Campland: Racial segregation of Roma in Italy. Budapest: European Roma Right Centre, 2000.

Grill J. (2011). From Street Busking in Switzerland to Meat Factories in the UK: A Comparative Study of Two Roma Migration Networks from Slovakia / In: Kaneff, D., Pine, F. (Eds). Emerging Inequalities in Europe: poverty and transnational migration. London: Anthem Press. Pp. 79-102.

Grill J. (2012). "It's building up to something and it won't be nice when it erupts": The making of Roma / Gypsy migrants in post-industrial Scotland // Focaal. 62 (1). Pp. 42-54.

Grill J. (2012). 'Going up to England': Exploring Mobilities among Roma from Eastern Slovakia // Journal of Ethnic and Migration Studies. 38 (8). Pp. 1269-1287.

Klimova I., Pickup A. (2000). (Eds.) Romani Migrations: Strangers in Anybody’s Land? // Cambridge Review of International Affairs. XIII (2). Pp. 13-118.

Kotvanova A., Szep A. (2002). (Eds.) Migrácia a Rómovia. Historické sociálne a politické súvislosti. Bratislava: Slovenský inštitút medzinárodných štúdii.

Kovats A. (2002). (Ed.) Roma Migrations. Budapest: Hungarian Academy of Sciences - Institute of Minority Research.

Marushiakova E. (2008). Gypsy/Roma Identities in New European Dimension: The Case of Eastern Europe / In: Marushiakova E. (Ed.) Dynamics of National Identity and Transnational Identities in the Process of European Integration. Newcastle: Cambridge Scholars Publishing. Pp. 468-490.

Marushiakova E. (2014). Roma from Southeastern Europe: Living and Working in Migration // Re:work Working Paper. 15. Pp. 281-309. 
Marushiakova E., Popov V. Gypsies (1997). (Roma) in Bulgaria. Frankfurt am Main: Peter Lang.

Marushiakova E., Popov V. (2006). De l'Est a l'Ouest. Chronologie et typologie des migrations tsiganes en Europe // Etudes Tsiganes. No. 27-28. Pp. 10-26.

Marushiakova E., Popov V. (2008). Migrations des Tsiganes en Europe, des ann es soixante a nós jours // Hommes et Migrations. 1275. Pp. 100-111.

Marushiakova E., Popov V. (2012). Gypsy migrations in Europe / In: Migration bridges in Eurasia. Collection reports and materials of the participants of the II international scientific-practical conference. Ed. by S.V. Ryazantsev. Moscow: Econ-Inform. Pp. 261-265.

Marushiakova E., Popov V. (2013). Roma Identities in Central, Southeastern and Eastern Europe / In: Kyuchukov, H., Rawashdeh, O. (Eds.) Roma Identity and Anti-Gypsyism in Europe. München: LINCOM. Pp. 40-52.

Marushiakova E., Popov V. (2013). Two Patterns of Roma Migrations from Southeastern Europe / In: Dimitrova, T., Kahl, T. (Eds.) Migration from and towards Bulgaria. Berlin: Frank and Timme. Pp. 227-244.

Marushiakova E., Popov V. (2013). Roma Migrations vs. Gypsy Nomadismus / In: SchrammelLeber, B., Tiefenbacher, B. (Eds.) Romani V. Papers from the Annual Meeting of the Gypsy Lore Society, Graz 2011. Graz: Grazer Linguistische Monographien. Pp. 113-134.

Марушиакова Е., Попов В. (2013). Миграции на цигани от Юго-Източна Европа. (История и съвременност) / In: Маева, М., Захова, С. (Eds.) Българите в Средиземноморието. Етнография на миграциите. София: Парадигма. Рp. 237-296.

Marushiakova E., Popov V. (2015). European Gypsy Migrations: Historical and Modern Patterns / In: Migration bridges in Eurasia. Materials of the VII international scientific and practical conference. Ed. by S.V. Ryazantsev. Moscow: Econ-Inform. Pp. 404-409.

Marushiakova E., Popov V. (2015). European Policies of Roma Social Inclusion: Catch 22? // Social Inclusion. 3 (5). P. 19-31.

Marushiakova E., Popov V. (2015). Identity and Language of the Roma (Gypsies) in Central and Eastern Europe / In: Kamusella, T., Nomachi, M., Gibson, C. (Eds.) The Palgrave Handbook of Slavic Languages, Identities and Borders. London: Palgrave. Pp. 26-54.

Marushiakova E. (2001). et al. Identity Formation among Minorities in the Balkans: The cases of Roms, Egyptians and Ashkali in Kosovo. Sofia: Minority Studies Society Studii Romani.

Matras Y. (1998). The development of the Romani civil right movement in Germany 1945-1996 / In: Tebbut, S. (Ed.) Sinti and Roma: Gypsies in German-speaking society and literature. New York: Berghahn. Pp. 49-64.

Matras Y. (2000). Romani migrations in the post-communist era: Their historical and political significance // Cambridge Review of International Affairs. 2000. 13 (2). Pp. 32-50.

Matras Y. (2002). Romani. A Linguistic Introduction. Cambridge: Cambridge University Press.

Reyniers A. (1999). Evaluation of Gypsy Populations and their Movements in Central and Eastern Europe and in some OECD Countries, focusing on the issues of migration, application for asylum, demography and employment. Occasional Papers. Paris: OECD.

Vidra Z. (2013). (Ed.) Roma migration to and from Canada: The Czech, Hungarian and Slovak case. Budapest: CEU.

Захова С. (2013). Формални и неформални мрежи на българи в Италия / In: Маева, М., Захова, С. (Ред.) Етнография на миграциите: Българите в Средиземноморието. София: Парадигма. Рр. 101-136.

(C) E. Marushiakova, V. Popov, 2017 
Article history:

Received: 23 December 2016

Revised: 23 January 2017

Accepted: 18 February 2017

For citation:

Marushiakova E., Popov V. (2017) Current Trends in the Social-Economic Integration of Gypsy Migrants in the European Union. RUDN Journal of Economics, 25 (1), 112-121.

\title{
Bio Note:
}

Marushiakova Elena, PhD, Professor, School of History, University of St. Andrews, Scotland, UK; Institute of Ethnology and Folklore Studies with Ethnographic Museum at Bulgarian Academy of Sciences, Sofia (Bulgaria). Contact information: e-mail: emp9@st-andrews.ac.uk

Popov Vesselin, PhD, Professor, School of History, University of St. Andrews, Scotland, UK; Institute of Ethnology and Folklore Studies with Ethnographic Museum at Bulgarian Academy of Sciences, Sofia (Bulgaria). Contact information: e-mail: vp43@st-andrews.ac.uk

\section{СОВРЕМЕННЫЕ ТРЕНДЫ СОЦИАЛЬНО-ЭКОНОМИЧЕСКОЙ ИНТЕГРАЦИИ МИГРАНТОВ-ЦЫГАН В ЕВРОПЕЙСКОМ СОЮЗЕ}

\author{
Елена Марушиакова, Веселин Попов \\ Школа истории Университета Святого Эндрюса \\ Южная ул., 71, Св. Эндрюс, Шотландия, Великобритания \\ Институт этнологии и фольклора при этнографическом музее, Болгарская академия наук \\ ул. Московская, ба, София, Болгария, 1000
}

Цыгане не являются изолированной группой, они обладают многомерными идентичностями и обладают национальной самобытностью. Чтобы выявить природу и факторы цыганских миграций, им следует уделять внимание как этнически специфической общности. Цыганские миграции и в прошлом и в настоящем обусловлены коллективными стратегиями в ответ на текущие политические и экономические изменения. Кажущаяся несогласованность цыганских миграций объясняется неоднородностью самих цыганских общин и по-разному проявляется в различных странах. В настоящее время главными носителями миграции являются не общины кочевников, а представители оседлых цыганских общин. Причиной тому является повышение степени интеграции цыган в странах Восточной Европы. Это приводит к включению цыган в глобальные миграционные процессы.

Ключевые слова: миграционный кризис, миграция цыган, интеграция цыган, этническая идентичность, Европейский Союз

\author{
История статьи: \\ Дата поступления в редакцию: 23 декабря 2016 \\ Дата принятия к печати: 18 февраля 2017
}




\section{Для цитирования:}

Марушиакова Е., Попов В. Современные тренды социально-экономической интеграции мигрантов-цыган в Европейском Союзе // Вестник Российского университета дружбы народов. Серия: Экономика. 2017. Т. 25. № 1. С. 112-121.

Сведения об авторах:

Елена Марушиакова, доктор наук, профессор Школы истории Университета Святого Эндрюса, Шотландия, Великобритания; Института этнологии и фольклора при этнографическом музее Болгарской академии наук. Контактная информация: e-mail: emp9@standrews.ac.uk

Весселин Попов, доктор наук, профессор Школы истории Университета Святого Эндрюса, Шотландия, Великобритания; Института этнологии и фольклора при этнографическом музее Болгарской академии наук. Контактная информация: e-mail: vp43@st-andrews.ac.uk 